\title{
Training of Information Ability of Young Teachers in Military Academies in the Era of Big Data
}

\author{
Yi Zhang ${ }^{1}$ Haishan Wang ${ }^{1}$ Ting Wei ${ }^{1}$ Junfei Bi ${ }^{1}$ Hui Liu ${ }^{1}$ Mengqi Zhang ${ }^{1, *}$ \\ ${ }^{1}$ College of Information and Communication, National University of Defense Technology, Xi'an, Shaanxi \\ 710106, China \\ "Corresponding author. Email: zmqsbsyf123@126.com
}

\begin{abstract}
Literature analysis and empirical study are employed in the paper to analyze the features of big data era: all is number, value of data, and "intelligentization" of the world. The significant role of big data on military and education is elaborated as follows: big data constitutes the core military combat effectiveness, big data subverts existing understanding of data value in educational research, and big data requires more for young teachers in military academies. The rich connotation of information ability in the context of big data is also clarified. The paths to deepen the training of young teachers' information-based ability in military academies are proposed, namely, training on demand and valuing the special needs of teachers, integrating resources and carrying out network mutual learning, combining teaching and research and promoting abilities.
\end{abstract}

Keywords: Big data, Information Ability, Young teachers.

\section{INTRODUCTION}

Training of information ability of young teachers in military academies in the era of big data refers to the process in which young teachers and institutions (departments) specialized in teacher training in military academies focuses on the impact of big data on military education practices in the new era based on the information ability of young teachers, combined with the characteristics of big data, and continuously better the information ability of young teachers.

\section{THE FEATURES OF BIG DATA}

The further development and extensive application of information and network technology have brought mankind into the era of big data. The development process of big data is characterized with "4V", namely volume (huge amount of data and data integrity), velocity (real-time requirement for data creation and processing), variety (diverse data types) and value (the intrinsic correlation discovered between massive and varied data). As a result, the era of big data features all is number, value of data, and "intelligentization" of the world, etc. Meanwhile, it endows people with new thinking.

\subsection{All Is Number}

Recently, the criteria adopted by human beings to quantify the objective world has changed as people attempts to measure the world with data and explore and understand the world. The popularization and application of the Internet and Internet of Things brought people into the era of "numeralization" of everything. All activities, from objective to subjective, from concrete to abstract, from macro to micro, are directly (or indirectly) recorded as digital information. Such "numeralization" leads to quantitative thinking. Therefore, the latest and most advanced technological means must be applied to quantitatively collect, analyze, discover and describe sea of information, and appropriate analytical method and data science for quantification and information sharing should be established to realize the value of data.

\subsection{Value of Data}

In the era of big data, more attention has been paid to the mining and utilization of data value, 
which is mainly reflected in the fact that the integrity and multi-dimensionality of data greatly sway the development process and result of things. Report by The McKinsey Global Institute (MGI) reveals that big data has covered every aspect and every field of social life and become an essential factor of production. The application of mass data heralds a new wave of value-added productivity. In other words, data equals value. However, the increasing popularity of data and more access makes the value of data no longer limited to data pooling, but more on the understanding, analysis and application of data, which indicates that big data allows new dimensions of value.

\section{3 "Intelligentization" of the World}

The two features analyzed above, coupled with the progress of big data, lead to human being's further understanding of the natural world and natural phenomena over time. Big data has served as an important basis for intelligence, and applications based on big data are smarter. The intelligence of big data in many fields can be found in people's daily life. The "intelligentization" of the world refers to the process from perception to memory to thinking, among which perception is the ability to obtain external information, while memory and thinking the ability to store and analyze the information acquired, which coincides with the process of big data mining. Human wisdom is harnessed to classify and manage data, a process known as "wisdom thinking". It's obvious that "wisdom thinking", which is indispensable for big data to better serve mankind, has become an important social thinking.

\section{THE SIGNIFICANT ROLE OF BIG DATA ON MILITARY AND EDUCATION}

\subsection{Big Data Constitutes the Core Military Combat Effectiveness}

Big data, serving as both information base and trump card, will subvert the form of future warfare. Most military theorists posit that IT-based war is essentially to minimize the enemy's information edge by means of information operations, so as to dominate in information on the battlefield. Given the critical role of data in influencing and determining military operations, the amount of data accumulated, the status of data collection, data analysis, and data mining will be the decisive factors to determine whether the combatant can take the initiative in the future battlefield. Real-time message in future battlefield will be distributed to commanders in the form of data, helping them to make sensible decisions. The ever-changing, numerous and complicated data constitute the most objective and basic battlefield situation, so big data itself is the focus of the war. Big data has been applied to defence-related science and technology, military training, etc. Such move has improved military management, broadened the application of military research methods, shortened the development cycle of weapons and equipment, enhanced the ability of intelligence analysis, reformed the way of command and decision, and optimized the process of operational command. It is no exaggeration to say that big data has transformed the form of future wars. Whoever has the "right to control data" will have the "right to control information".

\subsection{Big Data Subverts Existing Understanding of Data Value in Educational Research}

Big data collects information and applies data in a different way from traditional data. Big data emphasize more on negligible behaviors of students, freeing them from rote learning and excessive assignments. Systematic and controlled learning method that puts students in a better position to improve efficiency and receive feedback and guidance from teachers in a timely manner should be employed, backing personalized learning. Educators and researchers have developed five key techniques for extracting "value" from big data. ("Table 1") 
Table 1. Five key techniques for extracting "value" from big data

\begin{tabular}{|l|l|l|}
\hline Number & \multicolumn{1}{|c|}{ key techniques } & \multicolumn{1}{c|}{ Content } \\
\hline 1 & Prediction & The prediction of the possibility contributes to the control of all aspects of teaching. \\
\hline 2 & Clustering & The discovery of naturally clustered data points facilitates group teaching. \\
\hline 3 & Relationship mining & $\begin{array}{l}\text { Relationships between variables are discovered and used on the basis of careful } \\
\text { analysis, which clarifies whether students can improve their learning efficiency after } \\
\text { help-seeking. }\end{array}$ \\
\hline 5 & Distillation for human judgment & $\begin{array}{l}\text { Patterns of visual machine learning are established. } \\
\text { Meta-study is conducted through patterns developed through big data analysis. The } \\
\text { analysis of big data on learning ability helps to provide students with personalized } \\
\text { learning environment and courses, improving teaching methods, and effectively } \\
\text { enhancing students' learning effect. }\end{array}$ \\
\hline
\end{tabular}

\subsection{Big Data Requires More for Young Teachers in Military Academies}

The educational concept, teaching mode and teaching environment in the era of big data have changed significantly. The diversification of teaching mode is worth special attention, such as autonomous learning mode based on "resource", inquiry learning mode based on "problem", collaborative learning mode based on the "Internet", etc., which shows the complexity of young teachers from military academies, and the diversity of information communication channels between teachers and students. In addition to theoretical knowledge and practical ability, education by military academies in the era of big data should cover the comprehensive ability and quality of the students. Information ability contributes to the comprehensive quality of young teachers in military academies in the era of big data. The existing information ability of military teachers, especially young teachers, is the premise and foundation of cultivating information ability. Such ability guarantees the efficient and smooth communication between teachers and students, which backs the implementation of new teaching concept and teaching mode. Only with better information ability can young teachers in military academies meet the requirements of the new military revolution. The cultivation of the information ability of young teachers in military academies should stay current with the goal of building a world-class military and the construction of military informatization, so as to accelerate the development of their innovation in the context of IT-based war.

\subsection{The Rich Connotation of Information Ability in the Context of Big Data}

Many terms involving information emerge in the era of big data, such as information ability, information quality, information literacy, and data literacy. The term information literacy, first proposed by Paul Zurkowski, president of American Information Industry Association, in 1974, covers the meaning and requirements of information ability, information quality, and information literacy. Further research reveals that the connotation and denotation of the three terms vary. Information ability refers to the ability to understand, obtain and utilize information and to utilize information technology. 1 Information quality, a part of human quality, is a stable, basic and internal psychological quality formed by information knowledge, information awareness, education and environmental factors in human society. Its connotation includes four aspects: information awareness, information ability, information morality and life-long learning ability. ${ }^{2}$ Information literacy refers to the ability to adapt to information society, including the basic knowledge and skills about information and information technology, the ability to learn, cooperate, communicate and solve problems through information technology, as well as information awareness and social ethics and morality. ${ }^{3}$ The above indicates that the definition of information ability is relatively narrow, which only involves the basic ability of understanding, obtaining and applying information. Information literacy, on the other hand, covers information awareness, information morality and so on. Information quality shares the connotation of information literacy, with life-long learning ability added.

Information ability inherently includes two levels of "technology" and "humanity". As for

\footnotetext{
1 Baidu Encyclopedia. Information Ability. https://baike.baidu.com/item/\%E4\%BF\%A1\%E6\%81\%AF\%E8 $\% 83 \%$ BD\%E5\%8A\%9B [EB/OL].

2 Baidu Encyclopedia. Information Quality. https://baike.baidu.com/item/\%E4\%BF\%A1\%E6\%81\%AF\%E7 $\% \mathrm{~B} 4 \% \mathrm{~A} 0 \% \mathrm{E} 8 \% \mathrm{~B} 4 \% \mathrm{~A} 8$ [EB/OL].

3 Baidu Encyclopedia. Information Literacy. https://baike.baidu.com/item/\%E4\%BF\%A1\%E6\%81\%AF\%E7
} $\% \mathrm{~B} 4 \% \mathrm{~A} 0 \% \mathrm{E} 5 \% 85 \% \mathrm{BB}[\mathrm{EB} / \mathrm{OL}]$. 
technology, information ability reflects people's awareness and ability to utilize information. In terms of humanity, information ability reflects people's psychological moment facing information, in other words, their behaviors towards information. The concept of "information ability" proposed by the United States includes three levels (aspects): cultural level, namely knowledge, information awareness, namely awareness, and information skills, namely technology. "A person with information ability knows that accurate and complete information is the basis of rational decision-making. He can identify information needs, propose problems based on needs, identify potential information sources, and make successful retrieval plans." It is generally taken in the academic circle that information ability covers ten aspects, as shown in "Table 2":

Table 2 . Ten aspects covered by information ability

\begin{tabular}{|c|c|c|}
\hline Number & Ability & Content \\
\hline 1 & Ability to use information tools & $\begin{array}{l}\text { Proficient in using various information tools, especially Internet communication } \\
\text { tools }\end{array}$ \\
\hline 2 & $\begin{array}{l}\text { Ability to capture and obtain } \\
\text { information }\end{array}$ & $\begin{array}{l}\text { Effective collection of learning materials and information based on objectives. } \\
\text { Proficient in using reading, discussion, visiting, experiment, retrieval and other } \\
\text { means to obtain information. }\end{array}$ \\
\hline 3 & Ability to process information & $\begin{array}{l}\text { The ability to summarize, classify, store, identify, select, analyze, synthesize, } \\
\text { abstract, and express collected information. }\end{array}$ \\
\hline 4 & Ability to generate information & $\begin{array}{l}\text { The ability to accurately summarize, synthesize, and express the required } \\
\text { information on the basis of information collection, making it concise, easy to } \\
\text { understand and full of personality. }\end{array}$ \\
\hline 5 & Ability to create information & $\begin{array}{l}\text { Based on the interaction of collected information, the new growth point of } \\
\text { information is creatively endowed. }\end{array}$ \\
\hline 6 & $\begin{array}{l}\text { The ability to make information } \\
\text { work }\end{array}$ & Informat \\
\hline 7 & $\begin{array}{l}\text { The ability to collaborate on } \\
\text { information }\end{array}$ & $\begin{array}{l}\text { The establishment of harmonious cooperation with others by means of } \\
\text { information and information tools. }\end{array}$ \\
\hline 8 & Informational immunity & $\begin{array}{l}\text { Given the mixed information resources, it is necessary to carefully screen, } \\
\text { consciously resist and eliminate the interference and erosion of useless } \\
\text { information. }\end{array}$ \\
\hline 9 & Information awareness & $\begin{array}{l}\text { The ability to employ information for problem-solving with confidence and to } \\
\text { remain innovative and enterprising in any situation. }\end{array}$ \\
\hline 10 & Information ethics & $\begin{array}{l}\text { Ability to comply with ethical requirements, ethical norms, and ethical protocols } \\
\text { for information acquisition, development, dissemination, management, and } \\
\text { utilization. }\end{array}$ \\
\hline
\end{tabular}

No universal definition of information ability is seen yet. In view of the fact that information ability itself is born as a complex concept carrying several rich connotations, the understanding of its connotations largely determines its evaluation criteria and education practice. The scientific grasp of the connotation of information ability serves as the premise to determine the indicators of information ability of young teachers in military academies and to establish the objectives, contents and modes of information ability education.

Information ability refers to the literacy and ability of using information to solve problems. It should cover the basic ability of understanding, obtaining and applying information, as well as information awareness and information ethics. Information ability is an integral of the comprehensive ability and quality of military personnel and young teachers in military academies, and the basis and key of winning ITbased war. In the era of big data, young teachers in military academies serve as not only citizens of the information society, but also the one responsible for knowledge dissemination, skill training, and information ability enhancement of themselves and students. As a result, the information ability of young teachers in military academies enjoys double meaning, which includes the individual information ability as a citizen of the information society and the vocational information ability at a higher level as a young teacher in military academies. The former refers to information ability in a general sense, which mainly includes the ability to select, understand, question, evaluate and disseminate information. The latter is the essential ability of young teachers in military academies in the era of big data, which mainly includes the ability to effectively use information resources and means to promote teaching, the ability to promote selfdevelopment and the ability to help students improve their information ability. 


\section{THE PATHS TO DEEPENING THE TRAINING OF YOUNG TEACHERS' INFORMATION- BASED ABILITY IN MILITARY ACADEMIES}

\subsection{Training on Demand and Valuing the Special Needs of Teachers}

As for the cultivation of information ability of young teachers, the department tasked with enhancing personnel ability in military academies should adhere to the principle of "full coverage and on-demand treatment", and improve training efficiency based on the post requirements of young teachers. Relevant general training and the individualized needs of young teachers should be taken into account. The practices of Central China Normal University should be followed. For example, new teachers can be trained intensively to improve their information ability, while potential teachers with better information ability can be sent overseas for TPACK training, etc. to improve their information ability.

\subsection{Integrating Resources and Carrying Out Network Mutual Learning}

In the era of big data, research with the help of high-quality network resources is one of the main ways for young teachers in military academies to better themselves. The administrative institution and department tasked with enhancing personnel ability in military academies should integrate highquality network resources, take the initiative to establish or utilize famous teachers' courses to build groups to enhance personnel information ability, and encourage teachers, especially young teachers, to pick suitable courses for study and discussion. Experts can also be invited to build a complete network research system and promote the normalization of young teachers' information ability training.

\subsection{Combining Teaching and Research and Promoting Abilities}

One of the objectives of training information ability of young teachers in military academies is to enhance information-based classroom teaching and improve teaching and research. In the era of big data, education and teaching practice is a strong indicator of teachers' information ability. Activities such as demonstration of information-based teaching and information ability competition contribute to the application of teachers' information ability in practice. In addition, teachers should be encouraged to carry out research on the application of information ability, in a bid to deepen their understanding of educational informatization, improve their theoretical level and information ability in research and practice. The favorable environment for information-based teaching and research should also be created in military academies to stimulate young teachers' practice.

\section{CONCLUSION}

The improved information literacy of young teachers in military academies will further meet the requirements of training high-quality and specialized new military personnel, making new military reforms, and realizing the goal of strengthening the military.

\section{AUTHORS' CONTRIBUTIONS}

Yi Zhang was responsible for the overall design of the paper, Haishan Wang and Ting Wei wrote the manuscript, and Junfei Bi, Hui Liu and Mengqi Zhang revised and edited the paper.

\section{REFERENCES}

[1] UNESCO. ICT competency standards for teachers, 2008.

[2] Wei Dan. training of teachers' informationbased technology ability under the background of big data [J]. China Journal of Multimedia \& Network Teaching, 2020 (6): 120-121. (in Chinese)

[3] Guo Shaoqing, Wang Weijun. A Course of Information Technology Competency for Teachers [M]. Higher Education Press, 2010. (in Chinese)

[4] Ma Jianhua, He Changjiu. Research on the Significance and Countermeasures of Information Ability Training for Military Talents [J]. Journal of Artillery Academy, 2008, (2): 58-60. (in Chinese)

[5] Liu Ye, Liu Cunhai, Zhang Jilei, Zhou Mingyu. Exploration and Research on Technical Information Capability Cultivation 
of Military Cadets [J]. China Educational Technology \& Equipment, 2019. (in Chinese)

[6] Li Xinsong, Zhang Huan. Analysis of the Information Capacity of University Students Under the New Media Environment [J]. Journal of Modern Information, 2013. (in Chinese) 